\title{
Determinan Minat Berinfak Generasi Z di IAIN Padangsidimpuan
}

\author{
Sahrial Ependi Nasution', Kamaluddin², Rodame Monitorir Napitupulu ${ }^{3}$ \\ 1,2,3Institut Agama Islam Negeri Padangsidimpuan \\ 1,2,3Jl. T. Rizal Nurdin Km. 4,5 Sihitang 22733, Kota Padangsidimpuan \\ Email: rodamenapitupulu@iain-padangsidimpuan³
}

\begin{abstract}
Abstrak
Infak adalah dana yang dikeluarkan secara sukarela untuk suatu bunga yang diperintahkan oleh Islam. Namun hal tersebut belum terlaksana secara maksimal dikarenakan kendala mahasiswa yang tidak memiliki pendapatan tetap dan terjadi penurunan jumlah donasi, padahal jumlah mahasiswa yang merupakan generasi $\mathrm{Z}$ di IAIN Padangsidimpuan semakin meningkat. Tujuan dari penelitian ini adalah untuk mengetahui pengaruh religiusitas, pendapatan secara parsial dan simultan terhadap minat memberi infak pada generasi Z. Penelitian ini menggunakan penelitian kuantitatif dengan sumber data primer. Teknik pengumpulan data menggunakan teknik wawancara, kuesioner, dan dokumentasi dengan jumlah sampel 91 responden dan menggunakan random sampling. Analisis data yang digunakan adalah uji validitas, uji reliabilitas, uji normalitas, uji asumsi klasik, uji koefisien determinasi, uji hipotesis dan uji analisis regresi linier berganda. Hasil penelitian menunjukkan bahwa variabel pendapatan secara parsial tidak berpengaruh terhadap minat memberi pada generasi $Z$, sedangkan variabel religiusitas secara parsial berpengaruh terhadap minat memberi pada generasi $Z$. Secara simultan variabel religiusitas, pendapatan bersama berpengaruh terhadap minat memberi pada generasi $\mathrm{Z}$.
\end{abstract}

\section{Kata Kunci: Infak, Minat, Pendapatan, Religiusitas}

\begin{abstract}
Infaq is a fund issued voluntarily for an interest ordered by Islam. However, it has not been implemented optimally due to the constraints of students who do not have a fixed income and there has been a decrease in the number of donations, even though the number of students at IAIN Padangsidimpuan is increasing. The purpose of this study was to determine the effect of religiosity, income partially and simultaneously on the interest in giving infaq in $\mathrm{z}$ generation. This study uses quantitative research with primary data sources. Data collection techniques using interview techniques, questionnaires, and documentation with a sample size of 91 respondents and using random sampling. The data analysis used was validity test, reliability test, normality test, classical assumption test, determination coefficient test, hypothesis test and multiple linear regression analysis test. The results showed that the income variable did not partially influence the interest in giving in the z generation, while the religiosity variable had a partial effect on the interest in giving in the .z generation. Simultaneously, the religiosity variable, income together have an effect on the interest in giving in the $z$ generation
\end{abstract}

\section{Keywords: Infaq, Interest, Income, Religiosity}




\section{PENDAHULUAN}

Dalam agama Islam dikenal adanya dana sosial yang bertujuan untuk membantu kaum dhuafa. Sumber utama dana tersebut meliputi zakat, infak dan shadaqah, serta dapat ditambahkan wakaf dan dana investasi kebajikan. Dalam konsep agama Islam, zakat wajib dibayarkan oleh umatnya yang telah mampu dengan batas tertentu, sedangkan infak dan shadaqoh adalah dana yang dikeluarkan secara sukarela atau mengeluarkan sebagian dari harta atau pendapatan/penghasilan untuk suatu kepentingan yang diperintahkan oleh ajaran Islam (Sunardi et al., 2020).

Di Indonesia, infak diatur dalam undang-undang nomor 23 tahun 2011 yaitu tentang pengelolaan zakat pada BAB 1 pasal 1 yang menyatakan bahwa infak adalah harta yang dikeluarkan oleh seseorang atau badan usaha di luar zakat untuk kemaslahatan umum. Perkembangan infak Institut Agama Islam Negeri (IAIN) Padangsidimpuan mengalami fluktuasi, rata-rata jumlah infak per bulan di lingkungan IAIN Padangsidimpuan pada hingga tahun 2017 adalah Rp11.569.400,oo (pembulatan). Dengan jumlah mahasiswa yang kian meningkat di tiap tahunnya tentu seharusnya jumlah infak pun ikut meningkat. Ditambah lagi, mahasiswa di IAIN Padangsidimpuan telah menerima ilmu agama Islam yang baik serta merupakan generasi Z yang tahun kelahirannya berada pada rentang 1996-2010 yang pada dasarnya memiliki karakteristik yang senang berbagi (Pramisti, n.d.). Namun kenyataannya tidak demikian. Hal inilah yang menjadi ketertarikan peneliti, dimana tujuan peneltiian ini adalah untuk mengetahui determinan minat berinfak pada generasi $\mathrm{Z}$ di IAIN Padangsidimpuan.

\section{KAJIAN TEORITIS}

Infak berasal dari kata anfaqa yaitu mengeluarkan, membelanjakan (harta/uang). Infak adalah segala macam bentuk pengeluaran (pembelanjaan) baik untuk kepentingan pribadi, keluarga ataupun orang lain. Sedangkan menurut terminologi syariat, infak berarti mengeluarkan sebagian dari harta atau pendapatan/penghasilan untuk suatu kepentingan yang diperintahkan oleh ajaran Islam. (Suanrdi, 2020, p. hlm. 15) Sehingga dapat disimpulkan bahwa infak adalah segala sesuatu yang berkaitan dengan amal materi (harta/mal). Ketentuan Al-Qur'an tentang infak adalah jalan tengah yang proporsional, yaitu tidak bakhil, pelit, kikir dan juga tidak berlebihan. Allah SWT melarang berbuat bakhil, kikir, berbuat boros dan berlebihan sesuai dengan firman Allah SWT dalam surah Al-Furqan: 67.

Sementara itu, minat merupakan suatu keadaan atau kondisi dimana ketika seseorang telah mempunyai rasa ketertarikan pada hal tertentu yang diikuti dengan keinginan untuk belajar atau mempelajarinya, membuktikan serta mengetahui lebih dalam lagi akan suatu hal disebut. Pengertian minat yang lain yaitu perasaan, harapan, pendirian, kecenderungan serta prasangka yang bercampur dan terkumpul menjadi satu kesatuan yang bisa memberikan arah JISFIM: Journal of Islamic Social Finance Management, Volume 2, No 1 Tahun 2021 http://jurnal.iain-padangsidimpuan.ac.id/index.php/JISFIM 
kepada individu pada suatu pilihan dan atau keputusan (Tho'in \& Marimin, 2019). Faktorfaktor yang memengaruhi minat ada dua yaitu: faktor dari dalam (internal) yang berarti bahwa sesuatu perbuatan memang diinginkan karena seseorang senang melakukannya. Di sini minat datang dari diri orang itu sendiri. Di dalam penelitian ini yang merupakan faktor intrinsik adalah agama dan psikologis. Sedangkan yang kedua adalah faktor dari luar (eksternal) dimana berarti sesuatu perbuatan dilakukan atas dasar dorongan atau pelaksanaan dari luar. Orang melakukan kegiatan ini karena didorong atau dipaksa dari pihak luar. Seperti keluarga, teman, dan metode atau cara pembelajaran (Sunardi et al., 2020).

Faktor yang memengaruhi minat berinfak diantaranya adalah religiusitas dimana religiusitas adalah tingkat konsepsi seseorang terhadap agama dan tingkat komitmen seseorang terhadap agamanya. Tingkat konseptualisasi adalah tingkat pengetahuan seseorang terhadap agamanya, sedangkan yang dimaksud dengan tingkat komitmen adalah suatu hal yang perlu dipahami secara menyeluruh, sehingga terdapat berbagai cara individu untuk menjadi religius (Yazid, 2017). Religiusitas menurut Kamus Besar Bahasa Indonesia (KBBI) berarti taat kepada agama. Religiusitas dapat dikatakan sebagai ketaatan individu terhadap perintah agama yang diyakininya. Pengertian lain mengenai religiusitas yaitu "seberapa jauh pengetahuan, seberapa kokoh keyakinan, seberapa pelaksanaan kaidah dan ibadah, dan seberapa dalam penghayatan atas agama yang dianutnya (Asdiansyuri, 2020). Faktor lainnya yang memengaruhi minat berinfak adalah pendapatan (Janah, 2021; Mufitasari, 2019). Menurut KBBI, pendapatan bermakna sama dengan penghasilan (Arti Kata Hasil - Kamus Besar Bahasa Indonesia (KBBI) Online, n.d.).

Beberapa penelitian terdahulu sudah banyak dilakukan terkait faktor yang memengaruhi minat berinfak di Indonesia termasuk yang secara online diantaranya adalah (Andrini \& Auwalin, 2019; Janah, 2021; Mufitasari, 2019; Sunardi et al., 2020; Tho’in \& Marimin, 2019; Wahyuni, 2018; Wijaya, 2020; Yazid, 2017). Namun penelitian yang fokus pada generasi $\mathrm{Z}$ masih terbatas. Selain itu ada inkonsistensi pada hasil penelitian yang menyatakan bahwa terdapat pengaruh religiusitas dan pendapatan terhadap minat berinfak. Itulah sebabnya penelitian ini menjadi menarik diuji kembali.

\section{METODE PENELITIAN}

Peneliti dilakukan di Institut Agama Islam Negeri (IAIN) Padangsidimpuan yang beralamat di Jalan. HT. Rizal Nurdin, KM. 4,5 Sihitang, Padangsidimpuan Tenggara, Kota Padangsidimpuan, Sumatera Utara. Penelitian dimulai Januari 2021 - April 2021. Jenis penelitian yang dilakukan adalah jenis penelitian kuantitatif. Sedangkan informasi yang diperlukan diperoleh secara langsung pada objek penelitian dengan menyebarkan angket terhadap responden. Populasi merupakan wilayah generalisasi yang terdiri atas objek/subjek yang mempunyai kualitas dan karakteristik tertentu yang diterapkan peneliti untuk dipelajari

JISFIM: Journal of Islamic Social Finance Management, Volume 2, No 1 Tahun 2021 http://jurnal.iain-padangsidimpuan.ac.id/index.php/JISFIM 
kemudian ditarik kesimpulan. Dalam penelitian ini adalah jumlah keseluruhan mahasiswa ekonomi syariah semester 4 sebanyak 352 mahasiswa, semester 6 sebanyak 379 dan semester 8 sebanyak 317 mahasiswa sehingga total populasi 1.048 mahasiswa.

Sampel adalah sebagian dari subjek dalam populasi yang diteliti, yang sudah tentu mampu secara representatif dalam mewakili populasi. Besarnya sampel ditetapkan dengan menggunakan rumus Taro Yamane. Berjumlah 91 orang. Teknik pengambilan sampel yang digunakan probality sampling dengan jenis sampel yaitu sampel random sampling, dimana pengambilan sampel anggota sampel dan populasi dilakukan secara acak tanpa memperhatikan strata yang ada dalam populasi. Sumber data yang digunakan dalam penelitian ini adalah data primer. Data primer adalah data yang diperoleh secara langsung dari sumbernya, diamati, dan dicatat untuk pertama kalinya melalui wawancara atau hasil pengisian kuesioner kepada responden (Kuncoro, 2009, p. hlm. 157). Selanjutnya, data dianalisis dengan berbagai uji diantaranya: uji validitas, uji reliabilitas, uji normalitas, uji asumsi klasik, uji koefisien determinasi $\left(\mathrm{R}^{2}\right)$, uji hipotesis dan uji analisis regresi linier berganda.

\section{HASIL DAN PEMBAHASAN}

\section{Hasil Uji Validitas}

Uji validitas dilakukan untuk melihat apakah data yang diperoleh valid atau tidak valid. Uji validitas dilakukan dengan membandingkan nilai $r_{\text {hitung }}$ dengan $r_{\text {tabel }}$ untuk tingkat signifikan 0,1. Jika $r_{\text {hitung }}>r_{\text {tabel }}$ maka Item pernyataan dikatakan valid. Namun jika $r_{\text {hitung }}<r_{\text {tabel }}$ maka item pernyataan dikatakan tidak valid. Jadi $\mathrm{r}_{\text {hitung }}$ untuk tiap item pernyataan dapat dilihat dari kolom corrected item-totalcorrelation, tingkat signifikansi 0,1 dengan derajat kebebasan $(\mathrm{df})=\mathrm{n}-2, \mathrm{n}$ adalah jumlah sampel jadi $\mathrm{df}=91-2=89$, maka diperoleh angka pada $\mathrm{r}_{\text {tabel }}=0,1735$. Uji validitas dapat dilihat dari tabel berikut:

Tabel 1.

\section{Hasil Uji Validitas Faktor Religiusitas}

\begin{tabular}{|c|c|c|c|}
\hline Pernyataan & $\begin{array}{c}\mathbf{r} \\
\text { hitung }\end{array}$ & r table & Keterangan \\
\hline RLG 1 & 0,618 & \multirow{9}{*}{$\begin{array}{l}\text { Instrument valid jika } \mathrm{r} \text { hitung } \\
>\mathrm{r}_{\text {tabel}} \text {, dengan } \mathrm{df}=91-2=89 \\
\text { pada taraf signifikan } 10 \% \\
\text { maka nilai } \mathrm{r}_{\text {tabel }}=0,1735\end{array}$} & Valid \\
\hline RLG 2 & 0,662 & & Valid \\
\hline RLG 3 & 0,559 & & Valid \\
\hline RLG 4 & 0,786 & & Valid \\
\hline RLG 5 & 0,508 & & Valid \\
\hline RLG 6 & 0,712 & & Valid \\
\hline RLG 7 & 0,662 & & Valid \\
\hline RLG 8 & 0,786 & & Valid \\
\hline RLG 9 & 0,712 & & Valid \\
\hline
\end{tabular}

JISFIM: Journal of Islamic Social Finance Management, Volume 2, No 1 Tahun 2021 http://jurnal.iain-padangsidimpuan.ac.id/index.php/JISFIM 


RLG 10 $0,786 \quad$ Valid

Sumber: Data diolah (2021)

Berdasarkan hasil uji validitas religiusitas dapat disimpulkan bahwa 10 item pernyataan adalah valid. Berdasarkan $r_{\text {hitung }}<r_{\text {tabel }}$ dimana $r_{\text {tabel }}$ untuk $n=89$ adalah 0,1735 sedangkan $r_{\text {hitung }}$ dapat dilihat dari hasil item-totalcorrelation.

Tabel 2.

Hasil Uji Validitas Faktor Pendapatan

\begin{tabular}{|c|c|c|c|}
\hline Pernyataan & $\begin{array}{c}\mathbf{r} \\
\text { hitung }\end{array}$ & r table & Keterangan \\
\hline PDP 1 & 0,839 & \multirow{10}{*}{$\begin{array}{l}\text { Instrument valid jika } \mathrm{r} \text { hitung } \\
>\mathrm{r}_{\text {tabel}} \text {, dengan } \mathrm{df}=91-2= \\
89 \text { pada taraf signifikan } 10 \% \\
\text { maka nilai } \mathrm{r}_{\text {tabel }}=0,1735\end{array}$} & Valid \\
\hline PDP 2 & 0,546 & & Valid \\
\hline PDP 3 & 0,669 & & Valid \\
\hline PDP 4 & 0,562 & & Valid \\
\hline PDP 5 & 0,390 & & Valid \\
\hline PDP 6 & 0,641 & & Valid \\
\hline PDP 7 & 0,839 & & Valid \\
\hline PDP 8 & 0,669 & & Valid \\
\hline PDP 9 & 0,390 & & Valid \\
\hline PDP 10 & 0,839 & & Valid \\
\hline
\end{tabular}

Sumber: Data diolah (2021)

Berdasarkan hasil uji validitas pendapatan dapat disimpulkan bahwa 10 item pernyataan adalah valid. Berdasarkan $r_{\text {hitung }}<r_{\text {tabel }}$ dimana $r_{\text {tabel }}$ untuk $n=89$ adalah 0,1735

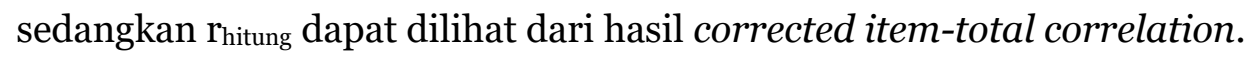

Tabel 3.

\section{Hasil Uji Variabel Minat}

\begin{tabular}{|c|c|c|c|}
\hline Pernyataan & r hitung & r table & Keterangan \\
\hline MB 1 & 0,440 & Instrument valid jika $\mathrm{r}$ & Valid \\
\hline MB 2 & 0,724 & hitung > r tabel, dengan & Valid \\
\hline MB 3 & 0,668 & $\mathrm{df}=91-2=89$ pada taraf & Valid \\
\hline MB 4 & 0,529 & signifikan $10 \%$ maka & Valid \\
\hline MB 5 & 0,541 & nilai $r$ tabel $=0,1735$ & Valid \\
\hline
\end{tabular}

Sumber : Data diolah (2021)

Berdasarkan hasil uji validitas minat dapat disimpulkan bahwa 5 item pernyataan adalah valid. Berdasarkan $\mathrm{r}_{\text {hitung }}<\mathrm{r}_{\text {tabel }}$ dimana $\mathrm{r}_{\text {tabel }}$ untuk $\mathrm{n}=89$ adalah $\mathrm{o}, 1735$ sedangkan $\mathrm{r}_{\text {hitung }}$ dapat dilihat dari hasil corrected item-totalcorrelation. 


\section{Hasil Uji Reliabilitas}

Uji reliabilitas bertujuan untuk mengukur kesesuaian instrumen (alat ukur) dengan yang diukur, sehingga instrumen tersebut dapat dipercaya. Suatu instrumen dikatakan reliabel jika Cronbach's Alpha. Jika $\mathrm{r}_{\text {tabel }}>$ o,6 maaka instrumen tersebut dinyatakan relibel dan jika $\mathrm{r}_{\text {tabel }}<\mathrm{o}, 6$ maka instrumen tersebut dinyatakan tidak reliabel. Hasil uji reliabilitas dapat dilihat dari tabel :

Tabel 4.

Hasil Uji Reliabilitas

\begin{tabular}{lccc}
\hline \multicolumn{1}{c}{ Variabel } & $\begin{array}{c}\text { Cronbach's } \\
\text { Alpha }\end{array}$ & $\begin{array}{c}\text { Tingkat } \\
\text { Kepercayaan }\end{array}$ & Keterangan \\
\hline Religiusitas & 0,719 & 0,6 & Reliabel \\
\hline Pendapatan & 0,673 & 0,6 & Reliabel \\
\hline Minat & 0,659 & 0,6 & Reliabel
\end{tabular}

Sumber: Data diolah, SPSS 24 Tahun 2021

Dari hasil data di atas menunjukkan bahwa Cronbach's Alpha untuk variabel reliusitas adalah 0,719 > 0,6 dapat disimpulkan variabel religiusitas $\left(\mathrm{X}_{1}\right)$ adalah reliabel. Selanjutnya Cronbach's Alpha untuk variabe pendapatan adalah o,6 > 0,673 dapat disimpulkan variabel pendapatan $\left(\mathrm{X}_{2}\right)$ adalah reliabel. Cronbach's Alpha untuk variabel minat adalah 0,659 > 0,6 dapat disimpulkan variabel minat (Y) adalah reliabel.

\section{Hasil Uji Normalitas}

Uji normalitas digunakan untuk melihat apakah nilai residual berdistribusi normal. Model regresi dikatakan baik apabila nilai residualnya berdistribusi normal. Dalam melakukan uji normalitas peneliti menggunakan uji One Sample Kolmogrov-Smirnov dengan taraf signifikan 0,1. Hasil uji normalitas dapat dilihat dari tabel berikut.

Tabel 5.

Hasil Uji Normalitas

One-Sample Kolmogorov-Smirnov Test

\begin{tabular}{llr} 
& & $\begin{array}{r}\text { Unstandardized } \\
\text { Residual }\end{array}$ \\
\hline $\mathrm{N}$ & Mean & 91 \\
\hline Normal Parameters & a,b & ,0000000 \\
\cline { 2 - 3 } & Std. Deviation & $\mathbf{1 , 9 6 8 8 0 1 9 8}$ \\
\hline Most Extreme Differences & Absolute &, 085 \\
\cline { 2 - 3 } & Positive &, 075 \\
\cline { 2 - 3 } & Negative &,- 085 \\
\hline Test Statistic & &, 085 \\
\hline
\end{tabular}

JISFIM: Journal of Islamic Social Finance Management, Volume 2, No 1 Tahun 2021 http://jurnal.iain-padangsidimpuan.ac.id/index.php/JISFIM 


\begin{tabular}{l}
\hline Asymp. Sig. (2-tailed) \\
\hline a. Test distribution is Normal. \\
b. Calculated from data. \\
c. Lilliefors Significance Correction.
\end{tabular}

Sumber : Data diolah (2021)

Dari tabel IV.13 diatas dapat dilihat hasil signifikansi religiusitas dan pendapatan terhadap minat berinfak (Asymp. Sig. (2-tailed) sebesar 0,111 > 0,1 dapat disimpulkan bahwa data berdistribusi normal dengan menggunakan uji One sampel kolmogorov-smirnov.

\section{Hasil Uji Linieritas}

Uji linieritas digunakan untuk mengetahui variabel independen (bebas) memiliki hubungan yang linier atau tidak terhadap variabel dependen (terikat). Hasil uji linieritas dapat dilihat dari tabel berikut.

Tabel 6.

Hasil Uji Linieritas Variabel Religiusitas ANOVA Table

\begin{tabular}{|c|c|c|c|c|c|c|c|}
\hline & & & $\begin{array}{l}\text { Sum of } \\
\text { Squares }\end{array}$ & Df & $\begin{array}{c}\text { Mean } \\
\text { Square }\end{array}$ & $\mathrm{F}$ & Sig. \\
\hline \multirow{5}{*}{$\begin{array}{l}\text { MT } \\
* \\
\text { RE }\end{array}$} & \multirow{3}{*}{$\begin{array}{l}\text { Between } \\
\text { Groups }\end{array}$} & (Combined) & 368,730 & 16 & 23,046 & 5,966 & ,000 \\
\hline & & Linearity & 305,666 & 1 & 305,666 & 79,132 & ,000 \\
\hline & & $\begin{array}{l}\text { Deviation from } \\
\text { Linearity }\end{array}$ & 63,063 & 15 & 4,204 & 1,088 &, 382 \\
\hline & Within Groups & & 285,842 & 74 & 3,863 & & \\
\hline & Total & & 654,571 & 90 & & & \\
\hline
\end{tabular}

Sumber: Data diolah (2021)

Berdasarkan tabel di atas nilai Sig. Sebesar 0,382. Jadi dapat disimpulkan nilai Sig. > 0,1 menunjukkan bahwa hubungan antara variabel religiusitas terhadap minat berinfak generasi Z di IAIN Padangsidimpuan adalah linier.

Tabel 7.

Hasil Uji Linieritas Variabel Pendapatan ANOVA Table

\begin{tabular}{|c|c|c|c|c|c|c|c|}
\hline & & & $\begin{array}{l}\text { Sum of } \\
\text { Squares }\end{array}$ & df & $\begin{array}{l}\text { Mean } \\
\text { Square }\end{array}$ & $\mathrm{F}$ & Sig. \\
\hline \multirow{5}{*}{$\begin{array}{l}\mathrm{MT}^{*} \\
\mathrm{PE}\end{array}$} & \multirow{3}{*}{$\begin{array}{l}\text { Between } \\
\text { Groups }\end{array}$} & (Combined) & 112,432 & 14 & 8,031 & 1,126 & 350 \\
\hline & & Linearity & 78,721 & 1 & 78,721 & 11,036 & ,001 \\
\hline & & $\begin{array}{l}\text { Deviation } \\
\text { from Linearity }\end{array}$ & 33,711 & 13 & 2,593 &, 364 & ,977 \\
\hline & \multicolumn{2}{|l|}{ Within Groups } & 542,139 & 76 & 7,133 & & \\
\hline & \multicolumn{2}{|l|}{ Total } & 654,571 & 90 & & & \\
\hline
\end{tabular}

Sumber: Data diolah (2021)

JISFIM: Journal of Islamic Social Finance Management, Volume 2, No 1 Tahun 2021 http://jurnal.iain-padangsidimpuan.ac.id/index.php/JISFIM 
Berdasarkan tabel di atas nilai Sig. Sebesar 0,977. Jadi dapat disimpulkan nilai Sig. > 0,1 menunjukkan bahwa hubungan antara variabel faktor pendapatan terhadap minat berinfak generasi Z di IAIN Padangsidimpuan adalah linier.

\section{Hasil Uji Asumsi Klasik}

Uji asumsi klasik ini pada dasrnya untuk melihat ada adu tidaknya signifikan antara variabel dan untuk melihat apakah terdapat ketidaksamaan varian dari residual satu pengamatan ke pengamatan lainnya.

\section{Hasil Uji Multikolinieritas}

Uji multikolinieritas bertujuan untuk melihat ada atau tidak korelasi yang kuat antara variabel independen dalam suatu model regresi linier berganda. Suatu model dikatakan baik apabila tidak terjadi multikolinieritas dengan melihat nilai VIF dan Tolerance, apabila VIF < Tolerance dan Tolerance > 0,1 maka dinyatakan tidak terjadi multikolinieritas. Berikut merupakan tabel uji multikolinieritas.

\section{Tabel 8.}

\section{Hasil Uji Multikolinieritas}

\section{Coefficients $^{\mathrm{a}}$}

\begin{tabular}{|c|c|c|c|c|c|c|c|}
\hline \multirow[b]{2}{*}{ Model } & \multicolumn{2}{|c|}{$\begin{array}{c}\text { Unstandardized } \\
\text { Coefficients }\end{array}$} & \multirow{2}{*}{$\begin{array}{l}\text { Standardized } \\
\text { Coefficients } \\
\text { Beta }\end{array}$} & \multirow[b]{2}{*}{$\mathrm{T}$} & \multirow[b]{2}{*}{ Sig. } & \multicolumn{2}{|c|}{$\begin{array}{c}\text { Collinearity } \\
\text { Statistics }\end{array}$} \\
\hline & B & $\begin{array}{l}\text { Std. } \\
\text { Error }\end{array}$ & & & & Tolerance & VIF \\
\hline $\begin{array}{l}\text { (Constant } \\
\text { ) }\end{array}$ & ,018 & 2,703 & & ,007 & ,995 & & \\
\hline $\mathrm{RE}$ & ,483 & ,064 & 689 & 7,567 & ,OOO & ,731 & 1,367 \\
\hline $\mathrm{PE}$ &,- 008 & ,o68 &,- 010 &,- 111 & ,912 & ,731 & 1,367 \\
\hline
\end{tabular}

a. Dependent Variable: MT

Sumber: Data diolah (2021)

Berdasarkan tabel di atas diketahui nilai Tolerance dari variabel religiusitas adalah 0,731 > 0,1 variabel pendapatan adalah 0,731>0,1. Jadi nilai Tolerance dari ke dua variabel lebih besar dari o,1 (nilai Tolerance $>0,1$ ) sehingga bebas dari multikolinieritas. Selanjutnya berdasarkan nilai VIF dari variabel pengetahuan adalah $1,367<10$ variabel religiusitas adalah 1,367 < 10. Jadi nilai VIF dari ke dua variabel lebih kecil dari 10 (nilai VIF < 10) sehingga tidak terjadi multikolinieritas.

\section{Hasil Uji Heteroskedastisitas}

Model regresi dikatakan baik apabila tidak terjadi heteroskedastisitas. Uji ini menggunakan uji glesjer yang dilakukan dengan cara meregresikan antar variabel independen dengan nilai absolut residualnya. Jika nilai signifikansi antara variabel independen dengan residual lebih dari o,1 maka tidak terjadi heteroskedastisitas. Berikut merupakan hasil uji heteroskedastisitas.

JISFIM: Journal of Islamic Social Finance Management, Volume 2, No 1 Tahun 2021 http://jurnal.iain-padangsidimpuan.ac.id/index.php/JISFIM 
Tabel 9.

\section{Hasil Uji Heteroskedastisitas \\ Coefficients $^{\mathbf{a}}$}

\begin{tabular}{|c|c|c|c|c|c|c|}
\hline \multirow[b]{2}{*}{ del } & & \multicolumn{2}{|c|}{$\begin{array}{l}\text { Unstandardized } \\
\text { Coefficients }\end{array}$} & \multirow{2}{*}{$\begin{array}{l}\text { Standardized } \\
\text { Coefficients } \\
\text { Beta }\end{array}$} & \multirow[b]{2}{*}{$\mathrm{t}$} & \multirow[b]{2}{*}{ Sig. } \\
\hline & & B & $\begin{array}{l}\text { Std. } \\
\text { Error }\end{array}$ & & & \\
\hline \multirow[t]{3}{*}{1} & $\begin{array}{l}\text { (Constant } \\
\text { ) }\end{array}$ & 6,040 & 1,792 & & 3,370 & ,001 \\
\hline & $\mathrm{RE}$ &,- 048 & ,o42 &,- 136 & $-1,132$ & ,261 \\
\hline & $\overline{P E}$ &,- 063 & ,045 &,- 168 & $-1,402$ & ,164 \\
\hline
\end{tabular}

a. Dependent Variable: Abs_Res

Sumber: Data diolah,SPSS 24 Tahun 2021

\section{Hasil Uji Koefisien Determinasi ( $\left.\mathbf{R}^{2}\right)$}

Koefisien Determinasi $\left(\mathrm{R}^{2}\right)$ dapat digunakan untuk mengetahui besarnya sumbangan atau kontribusi dari seluruh variabel independen (X) terhadap variabel dependen (Y) sedangkan sisanya dipengaruhi oleh variabel bebas yang tidak dimasukkan ke dalam model. Model dianggap baik jika koefisien determinan sama dengan satu atau mendekati satu. Adapun hasil analisis koefisien determinasi $\left(\mathrm{R}^{2}\right)$ sebagai berikut:

\section{Tabel 10.}

\section{Hasil Uji Koefisien Determinasi $\left(R^{2}\right)$}

\section{Model Summary}

\begin{tabular}{|c|c|c|c|c|}
\hline del & $\mathrm{R}$ & R Square & $\begin{array}{c}\text { Adjusted R } \\
\text { Square }\end{array}$ & $\begin{array}{c}\text { Std. Error of the } \\
\text { Estimate }\end{array}$ \\
\hline 1 &, $683^{\mathrm{a}}$ & ,467 & ,455 & 1,991 \\
\hline \multicolumn{5}{|c|}{ a. Predictors: (Constant), PE, RE } \\
\hline \multicolumn{5}{|c|}{ b. Dependent Variable: MT } \\
\hline \multicolumn{5}{|c|}{ Sumber: Data diolah (2021) } \\
\hline
\end{tabular}

Berdasarkan hasil tabel diatas dapat diketahui bahwa nilai $\mathrm{R}^{2}$ 0,455. Menunjukkan bahwa 45,5 variabel religiusitas, variabel pendapatan minat berinfak generasi Z di IAIN Padangsidimpuan sedangkan 54,5\% lagi dipengaruhi atau dijelaskan oleh variabel lain yang tidak dibahas dalam penelitian ini.

\section{Hasil Uji Parsial (Uji t)}

Uji parsial adalah pengujian seberapa jauh pengaruh satu variabel independen yaitu religiusitas, pendapatan secara individual dalam menerangkan variabel terikat. Berikut merupakan tabel uji parsial $(\mathrm{t})$. 
Tabel 11.

Hasil Uji Parsial (Uji t)

Coefficients $^{\mathbf{a}}$

\begin{tabular}{|c|c|c|c|c|c|c|}
\hline & & \multicolumn{2}{|c|}{ Unstandardized Coefficients } & \multirow{2}{*}{$\begin{array}{c}\text { Standardized } \\
\text { Coefficients } \\
\text { Beta }\end{array}$} & \multirow[b]{2}{*}{$\mathrm{T}$} & \multirow[b]{2}{*}{ Sig. } \\
\hline & & B & Std. Error & & & \\
\hline \multirow[t]{3}{*}{1} & $\begin{array}{l}\text { (Constant } \\
\text { ) }\end{array}$ & ,018 & 2,703 & & ,007 & 995 \\
\hline & $\mathrm{RE}$ & ,483 & ,064 & ,689 & 7,567 & ,000 \\
\hline & $\mathrm{PE}$ &,- 008 & ,068 &,- 010 &,- 111 & ,912 \\
\hline
\end{tabular}

a. Dependent Variable: MT

Sumber: Data diolah (2021)

Untuk $t_{\text {tabel }}$ dicari $\alpha=10 \%: 2=5 \%$ (uji dua sisi) dengan derajat kebebasan (Dr) $=n-k-$ 1, dimana $\mathrm{n}=$ jumlah sampel dan $\mathrm{k}=$ jumlah variabel independen, $(\mathrm{Dr})=91-2-1=88$. Dengan pengujian dua sisi (signifikansi $=0,05$ ), maka diperoleh $t_{\text {tabel }}=1,66235$. Berdasarkan hasil uji signifikansi parsial (uji t) di atas dapat dilihat bahwa pada variabel religiusitas memiliki $t_{\text {hitung }}$ sebesar 7,567 dan $t_{\text {tabel }}$ sebesar 1,66235 sehingga $t_{\text {hitung }}<t_{\text {tabel }}(7,567>1,66235)$ maka $H_{a}$ diterima. Jadi dapat disimpulkan bahwa secara parsial variabel religiusitas terdapat pengaruh terhadap minat berinfak generasi Z di IAIN Padangsidimpuan. Selanjutnya pada variabel pendapatan memiliki $t_{\text {hitung }}$ sebesar -111 dan $t_{\text {tabel }}$ sebesar 166235 sehingga $t_{\text {hitung }}<t_{\text {tabel }}(-111<$ 1,66235) maka $H_{a}$ ditolak. Jadi dapat disimpulkan bahwa secara parsial variabel pendapatan tidak terdapat pengaruh terhadap minat berinfak generasi $\mathrm{Z}$ di IAIN Padangsidimpuan.

\section{Hasil Uji Simultaan (Uji F)}

Uji $\mathrm{F}$ adalah pengujian signifikansi persamaan yang digunakan untuk mengetahui seberapa besar pengaruh variabel independen secara bersama-sama terhadap variabel dependen. Ketentuan dalam uji simultan (F) adalah jika $\mathrm{F}_{\text {htung }}<\mathrm{F}_{\text {tabel }}$ maka $\mathrm{H}_{\mathrm{O}}$ diterima dan jika $\mathrm{F}_{\text {htung }}>\mathrm{F}_{\text {tabel }}$ maka $\mathrm{H}_{\mathrm{O}}$ ditolak. Hasil uji simultan (F) dapat dilihat dari tabel berikut ini

\section{Tabel 12.}

Hasil Uji Simultan (Uji f)

ANOVA ${ }^{a}$

\begin{tabular}{|c|c|c|c|c|c|c|}
\hline \multicolumn{7}{|c|}{ ANOVA ${ }^{a}$} \\
\hline \multicolumn{2}{|l|}{ Model } & $\begin{array}{c}\text { Sum of } \\
\text { Squares }\end{array}$ & Df & $\begin{array}{c}\text { Mean } \\
\text { Square }\end{array}$ & $\mathrm{F}$ & Sig. \\
\hline \multirow[t]{3}{*}{1} & Regression & 305,715 & 2 & 152,858 & 38,559 &, $\mathrm{OOO}^{\mathrm{b}}$ \\
\hline & Residual & 348,856 & 88 & 3,964 & & \\
\hline & Total & 654,571 & 90 & & & \\
\hline
\end{tabular}

a. Dependent Variable: MT

b. Predictors: (Constant), PE, RE

Sumber: Data diolah,SPSS 24 Tahun 2021

JISFIM: Journal of Islamic Social Finance Management, Volume 2, No 1 Tahun 2021 http://jurnal.iain-padangsidimpuan.ac.id/index.php/JISFIM 
$F_{\text {tabel }}$ untuk signifikansi $\alpha=0,1$ dengan regression ( $\mathrm{df}$ 1) adalah 2 dan residual ( $\mathrm{df} 2$ ) adalah 88. Maka hasil untuk $F_{\text {tabel }}$ adalah 3,10. Dari hasil uji simultan (F) diatas bahwa nilai $F_{\text {hitung }}$ sebesar 38,559 sedangkan $F_{\text {tabel }}$ sebesar 3,10 sehingga $F_{\text {htung }}>F_{\text {tabel }}(38,559>3,10)$ maka $\mathrm{H}_{\mathrm{a}}$ diterima. Selanjutnya untuk nilai Sig. $>0,1(0,000<0,1)$ sehingga $\mathrm{H}_{\mathrm{a}}$ diterima. Jadi dapat disimpulkan bahwa secara simultan variabel religiusitas, pendapatan secara bersama-sama berpengaruh terhadap minat berinfak generasi Z di IAIN Padangsidimpuan.

\section{Hasil Analisis Regresi Linier Berganda}

Analisis regresi linier berganda yang digunakan dalam penelitian ini untuk mengetahui pengaruh faktor pengetahuan, faktor religiusitas, faktor pribadi dan faktor pelayanan terhadap keputusan menggunakan perbankan Syariah. Hasil analisis regresi linier berganda dapat dilihat dari tabel di bawah ini.

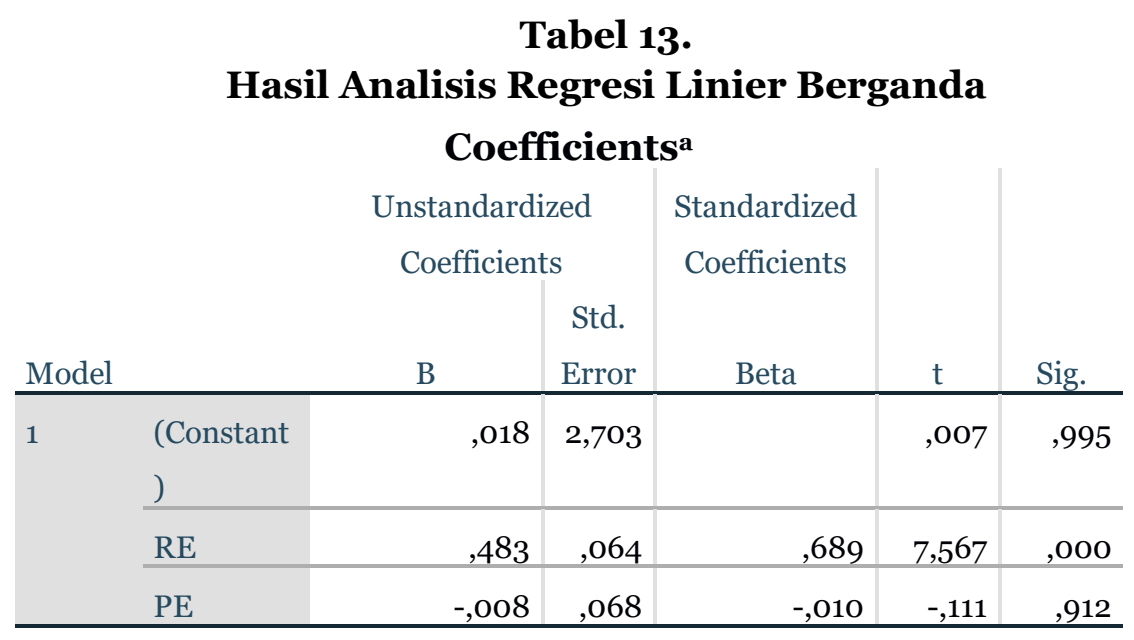

a. Dependent Variable: MT

Sumber: Data diolah,SPSS 24 Tahun 2021

Berdasarkan tabel di atas dapat dilihat pada kolom Unstandardized Coefficients bagian kolom B, maka persamaan analis regresi linier berganda dalam penelitian ini adalah:

$$
\begin{aligned}
& \mathrm{MT}=\alpha+\mathrm{b}_{1} \mathrm{RE}+\mathrm{b}_{2} \mathrm{PE}+\mathrm{e} \\
& \mathrm{MT}=\mathrm{o,18}+\mathrm{0,483}+\mathrm{o,008}-\mathrm{e}
\end{aligned}
$$

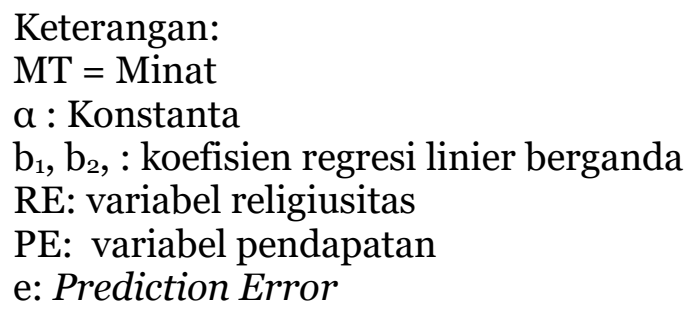


Dari persamaan regresi di atas dapat disimpulkan sebagai berikut

a. Nilai konstanta $(\alpha)$ bernilai positif sebesar o,18 menunjukkan bahwa variabel religiusitas, variabel pendapatan niainya $\mathrm{o}$, maka minat berinfak pada generasi z sebesar 0,18 satuan.

b. Nilai koefisien variabel faktor pengetahuan $\left(b_{1}\right)$ sebesar 0,483 , artinya apabila variabel religiusitas meningkat 1 satuan maka minat berinfak pada generasi z adalah meningkat sebesar 0,483 . koefisien bernilai positif artinya terjadi hubungan positif antara variabel religiusitas terhadap minat infak pada generasi z.

c. Nilai koefisien variabel pendapatan $\left(\mathrm{b}_{2}\right)$ sebesar -0,008, artinya apabila variabel pendapatan meningkat 1 satuan maka minat berinfak pada generasi $\mathrm{z}$ adalah meningkat sebesar -0,008 .Koefisien bernilai negatif artinya tidak terjadi hubungan positif antara variabel religiusitas terhadap minat berinfak pada generasi z.

Berdasarkan hasil uji parsial variabel religiusitas berpengaruh terhadap minat berinfak di IAIN Padangsidimpuan sehingga $t_{\text {hitung }}<t_{\text {tabel }}(7,567>1,66235)$. Hal ini menunjukkan bahwa religiusitas berpengaruh positif dan signifikan terhadap minat berinfak, sehingga dapat disimpulkan bahwa religiusitas berpengaruh secara parsial terhadap minat generasi $\mathrm{Z}$ dalam berinfak. Hal ini sejalan dengan teori Ghufron yang mengatakan bahwa religiusitas menunjuk pada tingkat keterikatan individu terhadap agamanya. Dan sejalan dengan penelitian yang dilakukan Indriana Retno Pangesti yang menyatakan bahwa religiusitas, pendapatan dan lingkungan berpengaruh positif dan signifikan terhadap motivasi masyarakat kecamatan kedaung kandang Kota Malang dalam membayar zakat, infak dan shodaqoh. Berdasarkan hasil analisis peneliti bahwa generasi Z di IAIN Padangsidimpuan berinfak karena keinginan mereka sendiri bukan karena paksaan.

Berdasarkan hasil uji parsial variabel pendapatan tidak berpengaruh terhadap minat berinfak pada generasi $\mathrm{z}$ bahwa variabel pendapatan memiliki $\mathrm{r}_{\text {hitung }}$ sebesar -111 dan $t_{\text {tabel }}$ sebesar 1,66235 sehingga $t_{\text {hitung }}<t_{\text {tabel }}(-111<1,66235)$. Hal ini menunjukkan bahwa pendapatan berpengaruh positif dan tidak signifikan terhadap minat berinfak, sehingga dapat disimpulkan bahwa pendapatan tidak berpengaruh secara parsial terhadap minat generasi $\mathrm{Z}$ dalam berinfak.

Pendapatan adalah penghasilan yang timbul dari aktivitas perusahaan yang biasa dan dikenal dengan sebutan yang berbeda seperti penjualan. Seperti hal nya penelitian Muhammad Tho'in dan Agus Marimin yang menyatakan bahwa pendapatan tidak berpengaruh terhadap minat membayar zakat pada Lazis Jateng Cabang Solo. Berdasarkan hasil analisis peneliti bahwa generasi $\mathrm{Z}$ di Padangsidimpuan tidak berminat infak karena belum memiliki penghasilan yang tetap ataupun pekerjaan.

JISFIM: Journal of Islamic Social Finance Management, Volume 2, No 1 Tahun 2021 http://jurnal.iain-padangsidimpuan.ac.id/index.php/JISFIM 


\section{KESIMPULAN}

Berdasarkan hasil penelitian dapat disimpulkan adalah secara parsial variabel religiusitas berpengaruh terhadap minat berinfak generasi Z di IAIN Padangsidempuan, namun variabel pendapatan tidak berpengaruh terhadap minat berinfak generasi $\mathrm{Z}$ di IAIN Padangsidempuan secara parsial. Sementara itu, secara simultan variabel religiusitas, variabel pendapatan berpengaruh terhadap minat berinfak generasi Z di IAIN Padangsidimpuan.

\section{DAFTAR PUSTAKA}

Andrini, J. F., \& Auwalin, I. (2019). Pengaruh Variabel Makro Ekonomi dan Penyaluran Zakat, Infak, dan Sedekah oleh Badan Amil Zakat Nasional terhadap Kemiskinan di Indonesia. Jurnal Ekonomi Syariah Teori Dan Terapan, 6(7), 1476-1493.

Arifin, G. (2016). Keutamaan Zakat, Infak, Sedekah Dilengkapi Dengan Tinjauan Dalam Fikih 4 MaZhab. Elex Media Komputindo.

Arti kata hasil-Kamus Besar Bahasa Indonesia (KBBI) Online. (n.d.). Retrieved May 10, 2021, from https://kbbi.web.id/hasil

Asdiansyuri, U. (2020). Analisis Pengaruh Religiusitas, Etika Bisnis Islam terhadap Minat Beli Online Mahasiswa (Studi Kasus pada STIE AMM Mataram).

Janah, B. S. J. (2021). FAKTOR-FAKTOR YANG MEMPENGARUHI BESARNYA INFAK YANG DIBAYARKAN PNS MUSLIM MELALUI BAZNAS KOTA MALANG. Jurnal Ilmiah Mahasiswa FEB, 9(2).

Kuncoro, M. (2009)., Metode Riset untuk Bisnis dan Eonomi Edisi 3. Erlangga.

Mufitasari, H. (2019). Pengaruh religiusitas muslim, citra lembaga dan pendapatan terhadap minat membayar zakat, infak Dan shodaqoh pada LAZISNU Wiradesa. [PhD Thesis]. IAIN PEKALONGAN.

Pramisti, N. Q. (n.d.). Tirto Visual Report: Masa Depan di Tangan Generasi Z. Tirto.Id. Retrieved May 10, 2021, from https://tirto.id//tirto-visual-report-masa-depan-ditangan-generasi-z-ctMM

Suanrdi, A. (2020). Minat Masyarakat Untuk Berinfak Melalui Platform Online. Jurnal Posiding Hukum Ekonomi Syariah, Vol. 6, No.2.

Sunardi, A., Surahman, M., \& Senjiati, I. H. (2020). Minat Masyarakat untuk Berinfak melalui Platform Online. Prosiding Hukum Ekonomi Syariah, 6(2), 669-672. https://doi.org/10.29313/syariah.v6i2.24397

Tho'in, M., \& Marimin, A. (2019). Pengaruh Tingkat Pendapatan, Tingkat Pendidikan, dan Tingkat Religiusitas Terhadap Minat Muzakki Membayar Zakat. http://jurnal.stieaas.ac.id/index.php/jei/article/view/678 
Wahyuni, B. (2018). Pengaruh Keimanan dan Altruisme (Kepekaan Sosial) terhadap Partisipasi Berinfak Jamaah Musalla al-Amin Ronowijayan Ponorogo [PhD Thesis]. IAIN Ponorogo.

Wijaya, D. G. (2020). Analisis Faktor-Faktor Yang Memengaruhi Minat Mahasiswa Berinfak Menggunakan Kitabisa. Com [PhD Thesis]. Universitas Brawijaya.

Yazid, A. A. (2017). Faktor-faktor yang Mempenagruhi Minat Muzakki dalam Menunaikan Zakat di Nurul Hayat Cabang Jember. Economic: Journal of Economic and Islamic Law, 8(2), 173-198. 